\title{
Somatic Embryogenesis from Roots of Camellia japonica Plantlets Cultured in Vitro
}

\author{
Ana M. Vieitez, Carmen San-José, F. Javier Vieitez, and Antonio Ballester \\ Plant Physiology, CSIC, Apartado 122, 15080 Santiago de Compostela, Spain
}

Additional index words. camellia, micropropagation, plant tissue culture, secondary embryogenesis

\begin{abstract}
Somatic embryos were induced on the roots of Camellia japonica L. plantlets regenerated from an in vitro clone of juvenile origin. The embryos appeared to differentiate from epidermic cells and to be connected with the root via a few parenchymatous cells. Somatic embryogenesis occurred on basal medium and with or without various combinations of zeatin, BA, and IBA. Secondary embryos were induced on cotyledons and/or hypocotyl regions of somatic embryos. Two morphological types of somatic embryos were developed, seed-like and bud-like types, and their formation was influenced by the presence of BA in the medium. Embryogenic capacity has been maintained for more than 24 months by subculturing secondary embryos at 7- to 8-week intervals. The best gibberellin/auxin combination for inducing the germination of isolated somatic embryos was $\mathrm{GA}_{3}$ at $5 \mathrm{mg} \cdot \mathrm{liter} \mathrm{G} \mathrm{A}_{3}$ and IAA at 1 $\mathrm{mg} \cdot$ liter $^{-1}$. P1antlets were successfully_ established in planting_medium and have continued to grow in a greenhouse. Chemical names used: $N$-(phenylmethyl)- $1 H$-purine-6-amine (BA); $(1 \alpha, 2 \beta, 4 a \alpha, 4 b \beta, 10 \beta)-2,4 a, 7$-trihydroxy-1-methyl8-methylenegibb-3-ene-1,10-dicarboxylic acid 1,4a-lactone $\left(\mathrm{GA}_{3}\right) ; 1 \mathrm{H}$-indole-3-acetic acid (IAA); $1 \mathrm{H}$ - indole-3-butyric acid (IBA); 2-methyl-4-(1 $H$ - purine-6-ylamino)-2-buten-1-ol (zeatin).
\end{abstract}

Shoot cultures based on axillary branching remains the preeminent in vitro method of camellia clonal multiplication from seedling-derived (Samartín et al., 1986) and from mature explants (San-José and Vieitez, 1990; Vieitez et al., 1989a, 1989b). Somatic embryogenesis might be an alternative mass propagation system. Somatic embryogenesis has been achieved from zygotic embryos of some Camellia spp. (Kate, 1989), but its extension to a wider range of older explants would be desirable. We found no reports of the regeneration of camellias by somatic embryogenesis from plantlets cultured in vitro.

Regeneration of plants from root tissue is not common. However, somatic embryos have been obtained on callus derived from intact roots of Prunus incisa $\times$ P. serrula and horse-chestnut (Aesculus hippocastanum L.) (Druart, 1981). Also, embryoid structures were induced on callus nodules developed on the roots of micropropagated cherry rootstock Colt (Prunus avium $\times$ P. pseudocerasus) plantlets (Jones et al., 1984). McCown (1986) developed highly competent embryogenic and organogenic systems based on the formation of nodules on the roots of Populus shoots rooted in vitro.

We report the induction of somatic embryos from roots of Camellia japonica L. plantlets raised in vitro, the maintenance of embryogenic capacity through secondary embryogenesis, and germination of somatic embryos into plants.

\section{Materials and Methods}

Micropropagated plantlets of three clones derived from in vitro shoot cultures of $C$. japonica were used as source material. Clones 1 and 2 were derived from 3- to 4-month-old seedlings and clone 3 from adult tissues obtained from a 50-year-old specimen of $C$. japonica 'Alba Plena'. The establishment of the shoot cultures from axillary buds has been described elsewhere (Samartín et al., 1984; Vieitez et al., 1989a, 1989b). Shoot multiplication cultures had been maintained for 2 years by subculturing at 7- to 8-week intervals on basal medium (see below) supplemented with BA at $1 \mathrm{mg} \cdot l i e^{-1}$ and IBA at $0.01 \mathrm{mg} \cdot$ liter $^{-1}$.

Received for publication 15 June 1990. This work was partially supported by CICYT, project no. BIO89-0529. The technical assistance of R. Fernández and C. García is acknowledged. The cost of publishing this paper was defrayed in part by the payment of page charges. Under postal regulations, this paper therefore must be hereby marked advertisement solely to indicate this fact.
For generating whole plantlets, rooting was induced by dipping the basal ends of 2- to $3-\mathrm{cm}$-long shoots in IBA at $1 \mathrm{~g} \cdot \mathrm{liter}^{-1}$ in $16 \%$ ethanol for $15 \mathrm{~min}$, after which the shoots were placed in 300-ml jars containing $60 \mathrm{ml}$ of basal medium, but with halfstrength macronutrients and no growth regulators. Cultures were initially incubated in the dark for 10 to 12 days and, thereafter, with $30 \mu \mathrm{mol} \cdot \mathrm{s}^{-1} \cdot \mathrm{m}^{-2}$ of light produced by cool-white fluorescent lamps for $16 \mathrm{~h} \cdot \mathrm{day}^{-1}$. The light/dark cycle was 26/20C.

Basal culture medium consisted of mineral salts of Murashige and Skoog's medium (1962) for clones 1 and 2 and Lloyd and McCown's medium (1980) for clone 3 (mg.liter ${ }^{-1}$ ), 1 thiamine, 0.1 nicotinic acid, 0.1 pyridoxine- $\mathrm{HCl}$; $\left(\mathrm{g} \cdot\right.$ liter $^{-1}$ ) 30 sucrose and 6 Difco agar. The $\mathrm{pH}$ was adjusted to between 5.5 and 5.6 before autoclaving.

After 1 month in rooting medium, rooted shoots were transferred to basal medium or basal medium supplemented with $\left(\mathrm{mg} \cdot \mathrm{liter}^{-1}\right) 1$ zeatin or 1 or $2 \mathrm{BA}$, alone or in combination with 0.1 or 1 IBA. Sixteen plantlets of each clone were tested in each medium combination (160 plantlets per clone). Cultures were incubated with $30 \mu \mathrm{mol} \cdot \mathrm{s}^{-1} \cdot \mathrm{m}^{-2}$ of light provided by coolwhite fluorescent lamps for $16 \mathrm{~h} \cdot \mathrm{day}^{-1}$, with a day/night of 26/20C. Percentage of plantlets exhibiting somatic embryos was recorded after 8 weeks. The experiment was conducted twice.

Secondary embryogenic capacity was evaluated for the two clones that produced somatic embryos (clones 1 and 2). Primary somatic embryos were isolated and subculture on the medium on which they had been obtained to increase the number of embryogenic cultures by repetitive embryogenesis. The competence of secondary embryogenesis was evaluated by transferring cotyledonary stage somatic embryos to basal medium alone or basal medium supplemented with BA at 1 or $2 \mathrm{mg} \cdot \mathrm{liter}^{-1}$ and/or IBA at 0.1 or $1 \mathrm{mg} \cdot$ liter $^{-1}$. For each treatment/clone combination, 40 somatic embryos were used (four replicate jars with 10 embryos each). Incubation conditions were the same as described previously. After 8 weeks, the percentage of embryos that had produced secondary embryos and the number of secondary embryos per responsive culture were recorded. Percentage data were transformed using arcsin of the square root and subjected to two-way analysis of variance (ANOVA). Significant differences between means was determined using Duncan's multiple range test.

Germination experiments were carried out with 5- to 9-mm- 

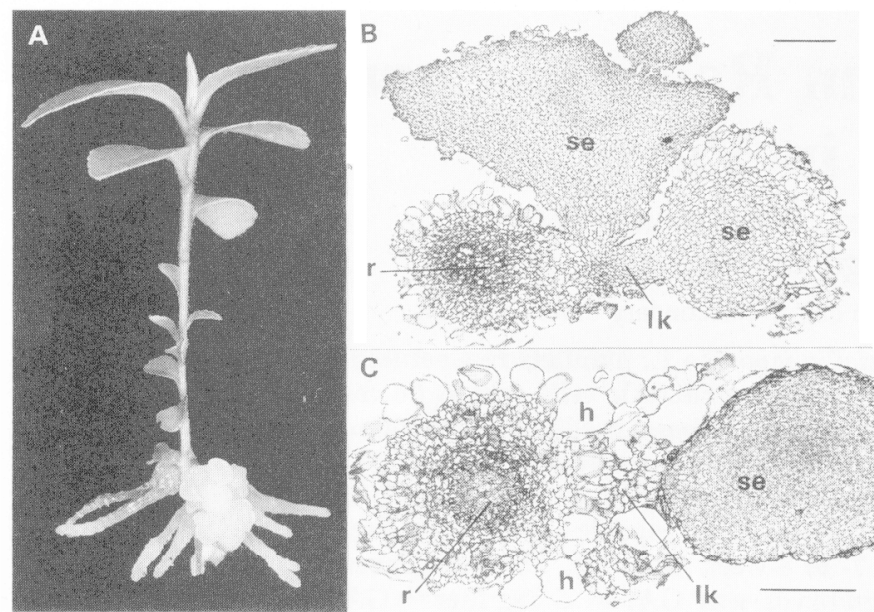

Fig. 1. Induction of somatic embryogenesis on adventitious roots of C. japonica raised in vitro. (A) Plantlet of clone 2 cultured on zeatin at $1 \mathrm{mg} \cdot$ liter $^{-1}$ for 8 weeks, showing somatic embryos. (B, C) Transverse sections of roots bearing somatic embryos. Globular and heartstage somatic embryos of clone 1 differentiated on basal medium without growth regulators $(\mathbf{B})$ and on medium with zeatin at 1 $\mathrm{mg} \cdot$ liter $^{-1}+$ IBA at $0.1 \mathrm{mg} \cdot \operatorname{liter}^{-1}(\mathbf{C}) . \mathrm{h}=$ hypertrophic epidermal cells; $r$ = adventitious root; $s e=$ somatic embryo; $\mathrm{Ik}=$ parenchymatic linkage between root and somatic embryo. Scale bar $=250$ $\mu \mathrm{m}$.

long "bud-like" secondary somatic embryos developed on BA at $1 \mathrm{mg} \cdot \mathrm{liter}^{-1}+\mathrm{IBA}$ at $0.1 \mathrm{mg} \cdot \mathrm{liter}^{-1}$. once isolated, the embryos were transferred to $300-\mathrm{ml}$ jars containing basal medium supplemented with $\mathrm{GA}_{3}$ at $1,2.5$, or $5 \mathrm{mg} \cdot$ liter $^{-1}$ with or without IAA at 1 or $2 \mathrm{mg} \cdot \operatorname{liter}^{-1}$. For each of the nine treatments tested, 30 somatic embryos were used (three replicate jars with 10 embryos each). Culture conditions were the same as described previously, although in some experiments the effect of a 15-day initial dark period at $24 \mathrm{C}$ was investigated. After 5 weeks, the percentage of embryos with roots, shoots, or both roots-and shoots longer than $5 \mathrm{~mm}$ was recorded. Length of roots and shoots was also determined. Percentage data were transformed using arcsin of the square root and subjected to one-way ANOVA. Significant differences between means were determined using Duncan's multiple range test.

Plantlets were transferred to pots (one-half liter) containing a mixture of 1 peat : 1 quartz sand, and placed under a plastic tunnel with a mist and fog system in a greenhouse. The programmed mist system ( 1 -sec burst every $2 \mathrm{~h}$ ) was complemented with an automatic fog system to give a relative humidity of $85 \%$ during the first 6 weeks of acclimatization. Weaning was carried out under natural daylight (April-May).

Tissues for histological examination were fixed in FAA (5 $\mathrm{ml}$ formalin $+5 \mathrm{ml}$ glacial acetic acid $+90 \mathrm{ml} \mathrm{50 \%}$ ethanol), embedded in paraffin wax, and $10-\mu \mathrm{m}$ sections cut and stained with safranin-fast green (Jensen, 1962).

\section{Results}

Induction of somatic embryogenesis Upon transfer to embryogenic medium, regenerated camellia plantlets each possessed four to six roots 10 to $12 \mathrm{~mm}$ long. Eight weeks later, average root length ranged from $14 \mathrm{~mm}$ for BA at $2 \mathrm{mg} \cdot \operatorname{liter}^{-1}$ to 26 $\mathrm{mm}$ for the basal medium.

No treatment induced somatic embryogenesis on plantlets of mature origin (clone 3). Somatic embryogenesis occurred with all treatments, including basal medium without growth regula-
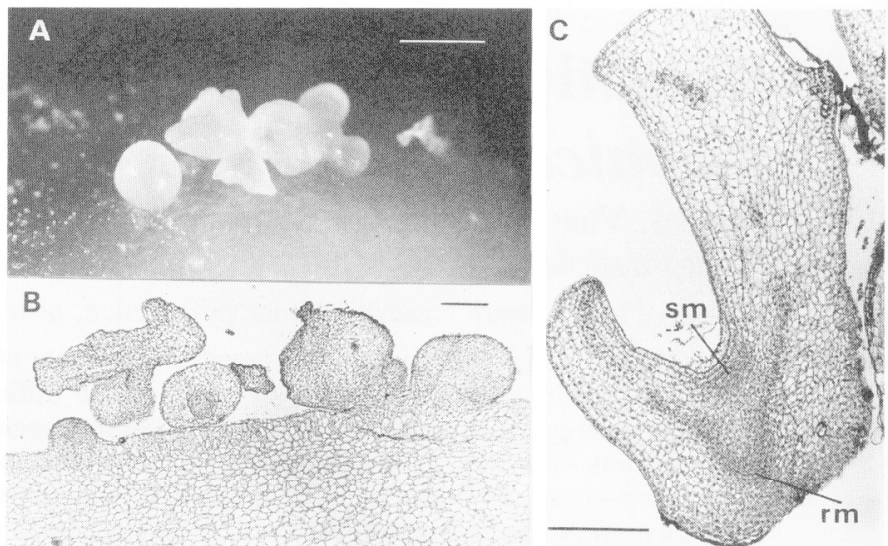

Fig. 2. Differentiation of secondary embryos. (A) Globular embryos differentiated directly on the surface of a cotyledon. (B) Microscopic sections corresponding to Fig. 2A. (C) Cotyledonary embryo showing vascular differentiation and both shoot $(\mathrm{sm})$ and root $(\mathrm{rm})$ meristems. Scale bars $=1 \mathrm{~mm}(\mathbf{A}), 250 \mu \mathrm{m}(\mathbf{B}, \mathbf{C})$.

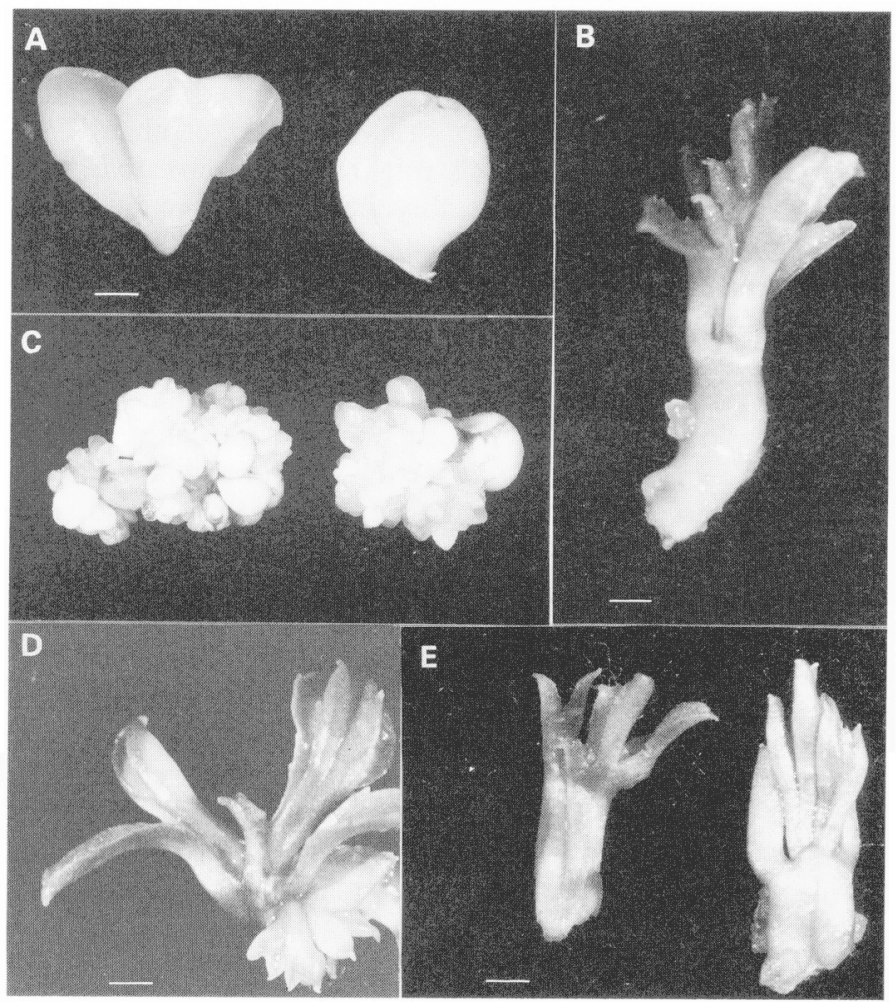

Fig. 3. Morphological types of somatic embryos in Camellia japonica. (A) Isolated seed-like embryos similar to the zygotic embryo. (B) Typical well-developed bud-like embryo with a secondary embryo differentiation in the hypocotyl zone. (C, D) Clumps of seedlike (C) and bud-like (D) secondary embryos. (E) Fused or fasciated bud-like somatic embryos. Scale bar $=1 \mathrm{~mm}$.

tors, for clone 2 with success rates ranging from $15 \%$ to $35 \%$ without any apparent relationship to treatment. The overall embryogenesis rate was $26 \%$ among the 160 plantlets of the first experiment and among the 154 of the second experiment (six plantlets were lost due to contamination). Similar results were obtained for clone 1, with an overall embryogenesis rate of $10 \%$ for 155 plantlets.

Yellow-white somatic embryos differentiated directly on plantlet roots either singly or in groups of up to seven 2 to 3 weeks after 
Table 1. Secondary embryogenesis of bud-like and seed-like somatic embryos of $C$. japonica clone 2 cultured on various media for 8 weeks.

\begin{tabular}{|c|c|c|c|c|c|c|c|c|}
\hline \multirow{3}{*}{$\begin{array}{l}\text { Medium } \\
\left(\mathrm{mg}^{\prime} \text { liter }^{-1}\right)\end{array}$} & \multicolumn{4}{|c|}{ Bud-like type } & \multicolumn{4}{|c|}{ Seed-like type } \\
\hline & \multirow{2}{*}{$\begin{array}{c}\text { Forming } \\
\text { embryos (\%) }\end{array}$} & \multirow[b]{2}{*}{$\mathrm{N}^{z, y}$} & \multicolumn{2}{|c|}{ Embryos formed $(\%)$} & \multirow{2}{*}{$\begin{array}{c}\text { Forming } \\
\text { embryos (\%) }\end{array}$} & \multirow[b]{2}{*}{$\mathrm{N}^{z, y}$} & \multicolumn{2}{|c|}{ Embryos formed $(\%)$} \\
\hline & & & Bud-like & Seed-like & & & Bud-like & Seed-like \\
\hline Basal medium & 83 & $45.5 \mathrm{a}$ & 8.9 & 91.1 & 85 & $26.6 \mathrm{ac}$ & 4.9 & 95.2 \\
\hline $\mathrm{BA}(1)$ & 71 & $19.0 \mathrm{~cd}$ & 46.3 & 53.7 & 60 & $16.3 \mathrm{~b}$ & 9.9 & 90.1 \\
\hline $\mathrm{BA}(2)$ & 75 & $28.2 \mathrm{bcd}$ & 74.4 & 25.6 & 53 & $10.3 \mathrm{bd}$ & 15.1 & 84.9 \\
\hline $\mathrm{BA}(1)+\operatorname{IBA}(0.1)$ & 62 & 27.1 bcd & 61.4 & 38.6 & 67 & $30.9 \mathrm{a}$ & 23.4 & 76.6 \\
\hline $\mathrm{BA}(1)+\mathrm{IBA}(1)$ & 84 & $37.5 \mathrm{ab}$ & 58.2 & 41.8 & 68 & $29.7 \mathrm{ac}$ & 24.8 & 75.2 \\
\hline $\mathrm{BA}(2) \cdot+\operatorname{IBA}(0.1)$ & 43 & $15.7 \mathrm{c}$ & 29.8 & 70.2 & 45 & $12.2 \mathrm{bd}$ & 15.4 & 84.6 \\
\hline $\mathrm{BA}(2)+\mathrm{IBA}(1)$ & 43 & $34.9 \mathrm{abc}$ & 46.4 & 53.6 & 28 & $5.9 \mathrm{~d}$ & 11.5 & 88.5 \\
\hline IBA $(0.1)$ & 83 & $51.1 \mathrm{a}$ & 4.5 & 95.5 & 82 & $32.9 \mathrm{a}$ & 3.0 & 97.0 \\
\hline IBA (1) & 72 & $38.7 \mathrm{ab}$ & 2.7 & 97.3 & 75 & $20.1 \mathrm{bc}$ & 2.7 & 97.3 \\
\hline
\end{tabular}

${ }^{2}$ Mean number of bud-like and seed-like secondary embryos per responding explant.

y Mean separation within columns by Duncan's multiple range test, $P=0.05$.

xPercentage of embryos formed according to morphological type.

transfer to embryogenic medium (Fig. 1A). Most embryos developed in the proximal region of a single root. Subsequent development of embryos was not synchronized, although most had reached the cotyledonary stage by 8 weeks on embryogenic induction medium. Somatic embryos appeared to differentiate from epidermic cells and to be connected to the root via a few parenchymatic cells, making them easily removable. No vascular connections were observed between root and embryo (Fig. $1 \mathrm{~B}, \mathrm{C})$. Some rounded, hypertrophic epidermal cells that were $\approx 20$ times larger than normal epidermal cells and possessed visible nuclei were also observed.

Secondary embryogenesis. Secondary somatic embryos developed on the hypocotyl and/or cotyledonary regions of previously differentiated embryos after 3 to 4 weeks in culture (Fig. 2 A-B). There were two morphological types of embryos: "seedlike" embryos had large, white, opaque cotyledons, whereas "bud-like" embryos had green cotyledons resembling true leaves (Fig. 3 A-D). Anatomical examination revealed the presence of shoot and root meristems in both types of embryos (Fig. 2C). Anomalies such as polycotyledony, cotyledon hypertrophy, or fascination (fusion of embryos at the hypocotyl/root level) were observed to different extents in both kinds of embryos (Fig. 3E).

Secondary embryos 8 to $9 \mathrm{~mm}$ long were subculture every 7 to 8 weeks. Embryogenic capacity declined when individual embryos <3 to $4 \mathrm{~mm}$ long were subculture, but successful subculture of groups of such immature embryos was possible.

For both embryo types of clone 2, secondary embryogenesis rate and number of secondary embryos per responsive embryo varied significantly $(P<0.005)$ with treatment factor, independently of the embryo type (Table 1 ). The results for clone 1 were similar. Best results were achieved in medium without growth regulators or medium supplemented with IBA at 0.1 $\mathrm{mg} \cdot \mathrm{liter}^{-1}$. Lowest rates of embryogenesis were recorded in medium containing BA at $2 \mathrm{mg} \cdot \mathrm{liter}^{-1}+\mathrm{IBA}$ at 0.1 or 1 $\mathrm{mg} \cdot \mathrm{liter}^{-1}$. Bud-like embryos produced significantly more secondary embryos than did seed-like embryos (Table 2), and their formation was influenced by the presence of BA. The largest percentages of bud-like embryos were obtained with BA at 1 $\mathrm{mg} \cdot \mathrm{liter}^{-1}+\mathrm{IBA}$ at $0.1 \mathrm{or} 1 \mathrm{mg} \cdot \mathrm{liter}^{-1}$ or (in the case of budlike embryos) BA alone at $2 \mathrm{mg} \cdot \mathrm{liter}^{-1}$ (Table 1). Fewer than $25 \%$ of the secondary embryos from seed-like primary embryos were bud-like, compared with $>50 \%$ for bud-like embryos, using these treatments. Interacting effects between the influences of
Table 2. ANOVA for the effect of culture medium and embryo type on secondary embryo formation.

\begin{tabular}{llcccc}
\hline \hline Parameter & \multicolumn{1}{c}{ Source } & df & SS & MS & F \\
\hline$\%^{2}$ & Culture medium & 8 & 1.263 & 0.203 & $5.537^{* *}$ \\
& Embryo type & 1 & 0.064 & 0.064 & $1.736^{\mathrm{NS}}$ \\
& Interaction & 8 & 0.144 & 0.018 & $0.491^{\mathrm{NS}}$ \\
$\mathrm{N}^{\mathrm{y}}$ & Culture medium & 8 & 6028 & 753 & $3.699^{* *}$ \\
& Embryo type & 1 & 2744 & 2744 & $13.472^{* *}$ \\
& Interaction & 8 & 1771 & 221 & $1.087^{\mathrm{NS}}$ \\
\hline
\end{tabular}

zPercentage forming secondary embryos after arcsin transformation. yMean number of secondary embryos per responding explant. Ns,**Not significant or significant at $P=0.005$.

treatment and embryo type were not significant for embryogenesis percentage or mean number of secondary embryos (Table 2 ). The embryogenic competence of secondary embryos has been maintained for 24 months, with subcultures every 7 to 8 weeks.

Germination. Germination experiments used bud-like embryos because seed-like embryos had exhibited less germination capacity in preliminary experiments. Embryos developed on BA at $1 \mathrm{mg} \cdot \mathrm{liter}^{-1}+$ IBA at $0.1 \mathrm{mg} \cdot \mathrm{liter}^{-1}$ were used because those developed on BA at $2 \mathrm{mg} \cdot$ liter $^{-1}$ although more abundant, had high fascination rates. Five weeks on germination medium produced not only whole regenerated plantlets (Fig. 4) but also incompletely regenerated plantlets lacking either roots or shoots.

In preliminary experiments we observed poor germination (9\%) of bud-like embryos on basal medium. Germination was generally improved by treatments with $\mathrm{GA}_{3}$ either alone or in combination with IAA (Table 3). Media supplemented with $\left(\mathrm{mg} \cdot\right.$ liter $\left.^{-1}\right) 5 \mathrm{GA}_{3}+1$ or 2 IAA and $2.5 \mathrm{GA}_{3}+2$ IAA resulted in a significantly higher $(P=0.05)$ germination rate than the media with $\mathrm{GA}_{3}$ alone or with $\mathrm{GA}_{3}$ at $1 \mathrm{mg} \cdot \mathrm{liter}^{-1}+$ IAA at 1 or $2 \mathrm{mg} \cdot$ liter $^{-1}$. In general, length of shoots produced increased with increasing $\mathrm{GA}_{3}$ concentrations (significant in whole plantlets, $P=0.05$ ). Root length was not significantly affected by growth regulator treatments.

During the first 2 weeks after transfer of somatic embryos to germination medium, cotyledons grew and thickened, and a single tap root began to emerge; the shoots developed later. Media with only $\mathrm{GA}_{3}$ at $1 \mathrm{mg}$.liter ${ }^{-1}$ tended to favor the thickening and development into cotyledonary structures of the first leaves developed on the shoot, whereas those cultured with $\mathrm{GA}_{3}$ 


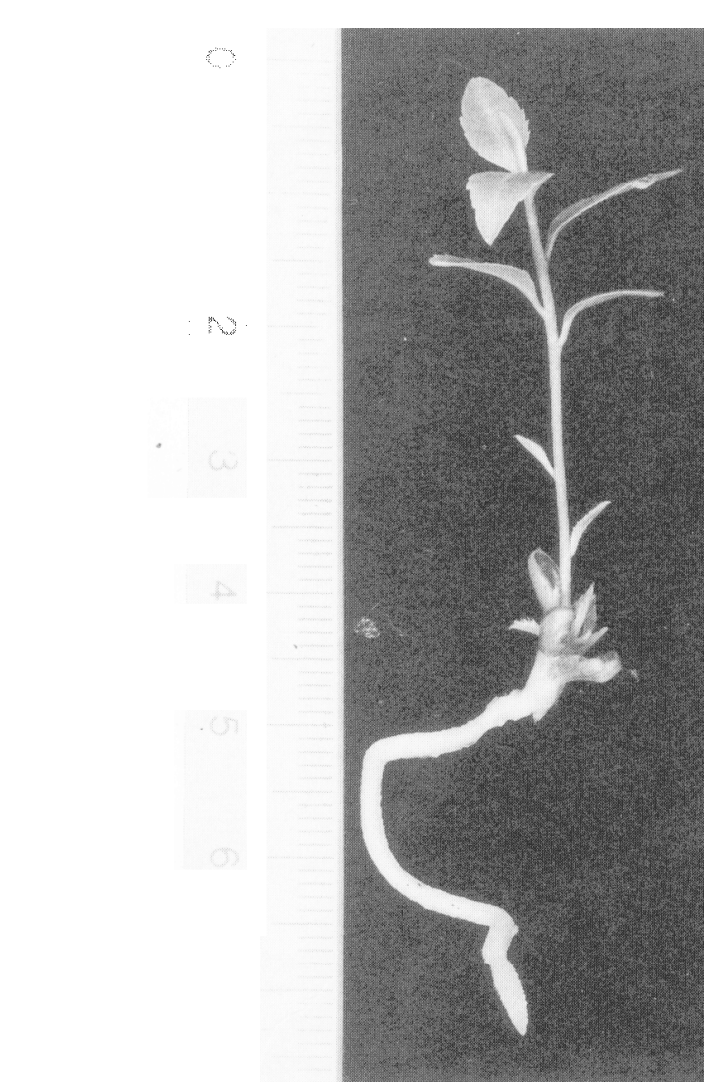

Fig. 4. Camellia japonica plantlet regenerated from a somatic embryo of clone 2 .

at $5 \mathrm{mg} \cdot$ liter $^{-1}$ induced thinner shoots with smaller leaves. Secondary embryogenesis sometimes occurred on the hypocotyl and proximal cotyledonary region during germination; it was more frequent when low $\mathrm{GA}_{3}$ concentrations were used. Secondary embryogenesis rates were lower and root growth was better when embryos were subjected to an initial 15-day dark period on germination media; with this treatment, $83 \%$ of somatic embryos developed primary roots.

Plantlets were successfully transferred into potting medium and plants were moved to the greenhouse 6 weeks after transfer to soil. They appeared morphologically similar to clonal material.

\section{Discussion}

We have developed an on-going somatic embryogenic system for $C$. japonica from plantlets regenerated from in vitro clones of juvenile origin. The somatic embryos developed directly on the roots of the plantlets, and there was no evidence of differentiation from callus.

Wann (1988) considered the pattern of indirect embryogenesis only if a true callus phenotype was described. In our experiments, primary somatic embryos appeared to differentiate directly from root epidermal cells, although a few parenchymatic cells linked the root to the embryo. A limited cell proliferation process observed before the direct differentiation of somatic embryos on cacao cotyledons might constitute a situation intermediate between direct and indirect embryogenesis (Duhem et al., 1989).

Growth regulator treatment had comparatively little effect on induction of somatic embryogenesis, which even occurred in basal medium. However, it is important to emphasize that rooting of camellia shoots has been induced by a pulse treatment in a very concentrated IBA solution. Direct somatic embryogenesis also takes place in hormone-free media from the hypocotyls and cotyledons of mature and immature zygotic embryos of C. reticulata and C. japonica (Plata and Vieitez, 1990; Vieitez and Barciela, 1990). Both phenomena appear to reflect the inherent capacity of these species to produce pre-embryogenic determined cells (Sharp et al., 1980) when physiologically juvenile. Conversely, the plantlets obtained from the 'Alba Plena' clone of adult origin failed to respond to any of the embryogenic treatments.

The long-term maintenance of secondary embryogenic competence by successive subcultures allows the creation of an embryogenic regeneration system that may not possess an embryogenic callus proliferation stage. A similar system using repetitive embryogenesis has been reported in other woody species such as walnut (Juglans regia L.) (Tulecke and McGranahan, 1985), eucalyptus (Eucalyptus citriodora Hook) (Muralidharan et al., 1989), and red currant 'F. Hosszúfurtü' (Ribes rubrum L.) (Zatyko et al., 1975). This system may prove

Table 3. Effect of $\mathrm{GA}_{3}$ and IAA on germination of somatic C. japonica embryos producing whole plantlets, rootlet shoots, and shootlet roots. Only shoots and roots longer than $5 \mathrm{~mm}$ were recorded after 5 weeks of culture. ${ }^{\mathrm{z}}$

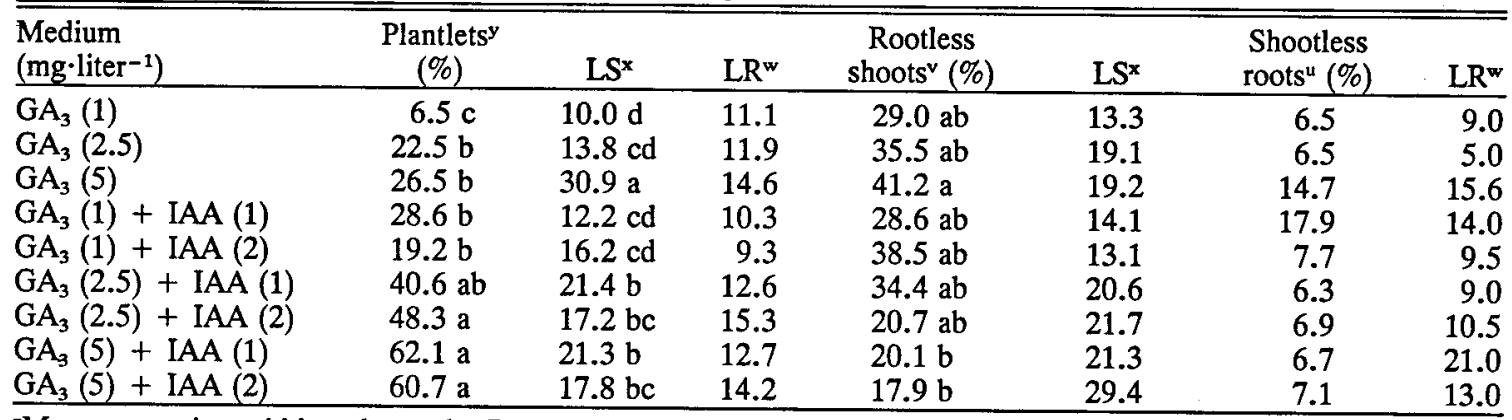

${ }^{2}$ Mean separation within columns by Duncan's multiple range test, $P=0.05$ : lack of letters indicates factor nonsignificant.

yPercentage of plantlets developed.

xMean length (mm) of shoots.

wMean length (mm) of roots.

vercentage of embryos producing only shoots.

"Percentage of embryos producing only roots. 
more efficient than shoot micropropagation methods (Samartín et al., 1984; Vieitez et al., 1989a, 1989b).

We observed two morphological types of somatic embryos similar to somatic embryos obtained from zygotic embryos of C. japonica (Vieitez and Barciela, 1990). According to Ammirato (1985), the bud-like type was differentiated with relatively high concentrations of cytokinins.

The somatic embryos used in the germination experiments had cotyledons smaller than those of the zygotic embryos, but their hypocotyl-root and shoot axes were well defined. The improvement of germination rates by $\mathrm{GA}_{3}$ has been reported in other woody species such as satsuma (Citrus unshiu Marc.) (Nito and Iwamasa, 1990) and horse-chestnut (Radojevic, 1988). Germination of the latter was enhanced, as in our experiments, from the inclusion of IAA in the medium. Kato (1986) used $\mathrm{GA}_{3}$ at $1 \mathrm{mg} \cdot \mathrm{liter}^{-1}$ to induce germination of somatic embryos of $C$. japonica obtained from cotyledon cultures, but she did not state the germination rates achieved. The rates obtained in our experiments using $\mathrm{GA}_{3}$ at $5 \mathrm{mg} \cdot \mathrm{liter}^{-1}+\mathrm{IAA}$ at $1 \mathrm{mg} \cdot \mathrm{liter}^{-1}$ were quite good compared with those reported for other woody species (Warm, 1988). However, a certain immaturity of germinating embryos was indicated by the tendency to form secondary cotyledons instead of true leaves, which has also been observed in cacao (Theobroma cacao L.) (Duhem et al., 1989) and red oak (Quercus rubra L.) (Gingas and Lineberger, 1989). The occurrence of secondary embryogenesis during germination is often associated with lack of maturity and failure to develop as a normal plantlet. This phenomenon presumably reflects the escape of certain cells from integrated group control (Williams and Maheswaran, 1986). Further control of embryogenic maturation along the lines employed by DeWald et al. (1989) for mango (Mangifera indica L.) seems to be necessary.

\section{Literature Cited}

Ammirato, P.V. 1985. Patterns of development in culture, p. 9-29. In: R.R. Henke, K.W. Hughes, M.J. Constantin, and A. Hollaender (eds.). Tissue culture in forestry and agriculture. Plenum, New York.

DeWald, S.G., R.E. Litz, and G.A. Moore. 1989. Maturation and germination of mango somatic embryos. J. Amer. Soc. Hort. Sci. 114:837-841.

Druart, P. 1981. Technique de régénération de plantules sur racines de ligneux cultivés in vitro. AFOCEL. Proc. Coll. Intl. sur la culture in vitro des essences forestières. IUFRO, Fontainebleau, France. p. 251-253.

Duhem, K., N. Le Mercier, and P. Boxus. 1989. Donnés nouvelles sur l'induction et le développement d'embryos somatiques chez Theobroma cacao L. Café Cacao Thé 33:9-14.

Gingas, V.M. and R.D. Lineberger. 1989. Asexual embryogenesis and plant regeneration in Quercus. Plant Cell Tissue Organ Culture 17:191203.

Jensen, V.A. 1962. Botanical histochemistry. Freeman, San Francisco. p. 55-99.

Jones, O.P., J.A. Gayner, and R. Watkins. 1984. Plant regeneration from callus tissue cultures of the cherry rootstock Colt (Prunus avium $\times$ P. pseudocerasus) and the apple rootstock Colt (Malus pumila). J. Hort. Sci. 59:463-467.

Kate, M. 1986. Micropropagation through cotyledon culture in $\mathrm{Ca}$ mellia japonica L. and C. sinensis L. Jpn. J. Breed. 36:31-38.

Kate, M. 1989. Camellia sinensis L. (Tea): In vitro regeneration, p. 82-98. In: Y.P.S. Bajaj (ed.). Biotechnology in agriculture and forestry, vol. 7. Medicinal and aromatic plants II. Springer-Verlag, Berlin.

Lloyd, G. and B. McCown. 1980. Commercially-feasible micropropagation of mountain laurel, Kalmia latifolia, by use of shoot tip culture. Proc. Intl. Plant Prop. Soc. 30:420-427.

McCown, B. 1986. Woody ornamentals, shade trees, and conifers, p. 333-342. In: R.H. Zimmerman, R.J. Griesbach, F.A. Hammerschlag, and R.H. Lawson (eds.). Tissue culture as a plant production system for horticultural crops. Martinus Nijhoff, The Netherlands.

Murashige, T. and F. Skoog. 1962. A revised medium for rapid growth and bioassays with tobacco tissue culture. Physiol. Plant. 15:473497 .

Muralidharan, E. M., P.K. Gupta, and A.F. Mascarenhas. 1989. Plantlet production through high frequency somatic embryogenesis in long term cultures of Eucalyptus citriodora. Plant Cell Rptr. 8:41-43.

Nito, N. and M. Iwamasa. 1990. In vitro plantlet formation from juice vesicles of satsuma (Citrus unshiu Marc.). Plant Cell Tissue Organ Culture 20:137-140.

Plata, E. and A.M. Vieitez. 1990. In vitro regeneration of Camellia reticulata by somatic embryogenesis. J. Hort. Sci. 65:707-716.

Radojevic, L. 1988. Plant regeneration of Aesculus hippocastanum L. (horse-chestnut) through somatic embryogenesis. J. Plant. Physiol. 132:322-326.

Samartín, A., A.M. Vieitez, and E. Vieitez. 1984. In vitro propagation of Camellia japonica seedlings. HortScience 19:225-226.

Samartín, A., A.M. Vieitez, and E. Vieitez. 1986. Rooting of tissue cultured camellias. J. Hort. Sci. 61:113-120.

San-José, M.C. and A.M. Vieitez. 1990. In vitro regeneration of $\mathrm{Ca}$ mellia reticulata $\mathrm{CV}$. 'Captain Rawes' from adult material. Scientia Hort. 43:155-162.

Sharp, W.R., M.R. Sondahl, L.S. Caldas, and S.B. Maraffa. 1980. The physiology of in vitro asexual embryogenesis. Hort. Rev. 2:268310.

Tulecke, W. and G. McGranahan. 1985. Somatic embryogenesis and plant regeneration from cotyledons of walnut, Juglans regia L. Plant Sci. 40:57-63.

Vieitez, A.M. and J. Barciela. 1990. Somatic embryogenesis and plant regeneration from embryonic tissues of Camellia japonica L. Plant Cell Tissue Organ Culture 21:267-274.

Vieitez, A.M., J. Barciela, and A. Ballester. 1989a. Propagation of Camellia japonica $\mathrm{CV}$. 'Alba Plena' by tissue culture. J. Hort. Sci. 64:177-182.

Vieitez, A.M., M.C. San-José, and A. Ballester. 1989b. Progress towards clonal propagation of Camellia japonica $\mathrm{CV}$. 'Alba Plena' by tissue culture techniques. J. Hort. Sci. 64:605-610.

Warm, S.R. 1988. Somatic embryogenesis in woody species. Hort. Rev. 10:153-181.

Williams, E.G. and G. Maheswaran. 1986. Somatic embryogenesis: factors influencing coordinated behaviour of cells as an embryogenic group. Ann. Bot. 57:443-462.

Zatyko, J.M., I. Simon, and C.S. Szabo. 1975. Induction of polyembryony in cultivated ovules of red currant. Plant Sci. Let. 4:281283. 